TAP̈ CHÍ PHAU் TRIEÅ KH\&CN, TAR̈ 16, SOÁK1- 2013

\title{
PREPARATION OF HIGH QUALITY POLYCRYSTALLINE SILICON THIN FILMS BY ALUMINUM INDUCED CRYSTALLIZATION
}

\author{
Tu Linh Phan, Duy Phong Pham, Bach Thang Phan, Cao Vinh Tran \\ University of Science, VNU-HCM \\ (Manuscript Received on April $5^{\text {th }}, 2012$, Manuscript Revised May 15 $5^{\text {th }}, 2013$ )
}

\begin{abstract}
In this paper, high-quality polycrystalline silicon (poly-Si) thin films on glass substrates are formed by Aluminum-induced crystallization (AIC). In AIC processes, bi-layer structures of amorphous silicon (a-Si) / Al are transformed into ones of (Al+ residual Si)/ poly-Si after simply annealing at $500^{\circ} \mathrm{C}$ in vacuum furnace. After Al chemical etchings, it isobserved that the obtained structures are poly-Si thinfilms on glasses with some amount of residual Si as "islands" scattered on theirsurfaces. The number of these "Si islands" remarkedly reduced by choosing an appropriate thickness ratio of pre-annealled Al and Si layers that prepared by magnetron dc sputtering. In this study, at initial Al/a-Si thickness ratio of 110/230 nm, the high-quality poly-Si thin films are formed with very few "Si islands" on the surfaces after AIC processes. Theobtained smooth surfaces are not appearing "dendritic" in optical transmission microscopy (OTM) images, have large grain size of tens of nanometers in SEM images and have average surface roughness of about $2.8 \mathrm{~nm}$ in AFM images. In addition, XRD $\theta-2 \theta$ measurements show a strong $\mathrm{Si}$ (111) peak at the $2 \theta$ angle of $28.5^{\circ}$, presenting good crystalline phases. The films also reveal good p-type electrical conductivityin that their high carrier concentration and mobility in Hall effect measurements are $10^{18} \mathrm{~cm}^{-3}$ and $48 \mathrm{~cm}^{2} / \mathrm{Vs}$, respectively.
\end{abstract}

Keywords: Aluminum-induced crystallization, polycrystalline silicon thin film.

\section{INTRODUCTION}

Polycrystalline silicon thin films on lowcost substrates prepared by aluminum-induced crystallization (AIC) technique are of great interest for electronic devices, such as solar cells and thin-film transistors. Crystallized $\mathrm{Si}$ films can be formed on foreign substrates using AIC at temperatures below the eutectic temperature in $\mathrm{Si}-\mathrm{Al}$ phase diagram. It is based on the overall layer exchange between adjacent $\mathrm{Si}$ and $\mathrm{Al}$ films during annealing process, resulting in the transformation from amorphous topolycrystalline $\mathrm{Si}$ phases. The advantages of the AIC technique are: a lowtemperature process $\left(<577^{\circ} \mathrm{C}\right.$, the eutectic temperature), large and homogenous silicon grains and $\mathrm{p}+$ type doping $(\mathrm{Al})$ of the resulting crystalline silicon layer. However, the obtained poly-Si thin films by AIC often contain " $\mathrm{Si}$ islands" on the surfaces [1]. These "Si islands" are attributed to have a negative effect on optical and electrical properties of films. Therefore,the preparation ofhigh-quality poly- 
$\mathrm{Si}$ thin films without $\mathrm{Si}$ islands is needed.

Many reports conducted the investigationson the morphology andthe structure of residual " $\mathrm{Si}$ islands", but no ones had clearindication on their formation mechanism as well asthe control of the amount of these remaining $\mathrm{Si}$ on surface of poly-Si thin films.

In this paper, the best poly-Si films, with very little amount of residual $\mathrm{Si}$ on the surfaces, are obtained by choosing proper thickness ratio of pre-annealled $\mathrm{Al}$ and $\mathrm{Si}$ layers in AIC process. After annealing and chemical etching $\mathrm{Al}$ by appropriate acid solution, the samples are evaluated by X-ray diffraction (XRD) measurements, scanning electron microscopy (SEM), optical transmission microscopy (OTM), atomic force microscopy (AFM), energy dispersive X-ray spectroscopy (EDX) analyses and Hall measurements.

\section{EXPERIMENTAL DETAILS}

Corning 7059 glassesare used as substrates for depositions. Both initial $\mathrm{Al}$ and $\mathrm{Si}$ layers are deposited at room temperature with operatingAr pressure of about $3.5 \times 10^{-3}$ torr by magnetron dc sputtering using Leybold Univex 450 system. At first, Al layers with various thicknesses such as $110 \mathrm{~nm}$ (A), $100 \mathrm{~nm}$ (B) and $90 \mathrm{~nm}$ (C) are deposited on the glass substrates at a fixed deposition rate of 1.19 $\mathrm{nm} / \mathrm{s}$ using $\mathrm{Al}(4 \mathrm{~N})$ target. All Al-coated glass substrates are exposed to air for $5 \mathrm{~min}$ to form a thin $\mathrm{Al}$ oxide layer on their surfaces prior to $\mathrm{Si}$ deposition. Then, a-Si layers with the same230 $\mathrm{nm}$ thicknesses are deposited onto these $\mathrm{Al}$ oxide layers at fixed $0.56 \mathrm{~nm} / \mathrm{s}$ rate using p-type silicon $(4 \mathrm{~N})$ target. When the a-Si depositions finish, the (a-Si/Al/glass) structures are annealed at $500^{\circ} \mathrm{C}$ for $5 \mathrm{~h}$ in vacuum furnace. The layer exchange process occurs to form Al layers on the top of the poly-Si layers. At last, top Al layers was etched off in standard $\mathrm{Al}$ etching solution (80\% phosphoric acid, 5\% nitric acid, 5\% acetic acid, 10\% DI water) for $4 \mathrm{~h}$ after the annealing process.

The samples characterizationsis performed using a variety of analytic techniques. The OTM, SEM (JEOL JSM-7401F), AFM (5500 AFM SYSTEM- AGILENT) are used to investigate the morphology of poly-Si films. The XRD (D8 ADVANCE - BRUKER) is used to evaluatethe degree of crystallizationand preferential orientation of obtained poly-Si thin films. EDX (JEOL JSM-7401F) is used to identify the contents of $\mathrm{Al}, \mathrm{Si}, \mathrm{O}$ elements in samples. The electrical properties of the samples are carried out by Hall effect measurement (Ecopia HMS-3000).

\section{RESULTS}

\subsection{Surface morphology}

After annealing and etching off residual $\mathrm{Al}$ by standard acid solution, samples are observed by optical transmission microscopy (Fig. 1). The sample A shows a surface that completely different from the others. There are very few"Si-islands" or "dendrites"observed on its surface. The image indicates that the film is continuous and smooth. This remark is

\section{Trang 58}


confirmed in SEM (Fig. 2) and AFM (Fig. 3) images. In contract, sample $\mathrm{B}$ or $\mathrm{C}$ is less smooth than sample A. There are a lot of "Siislands", presenting residual $\mathrm{Si}$ on their surfaces [1,2].
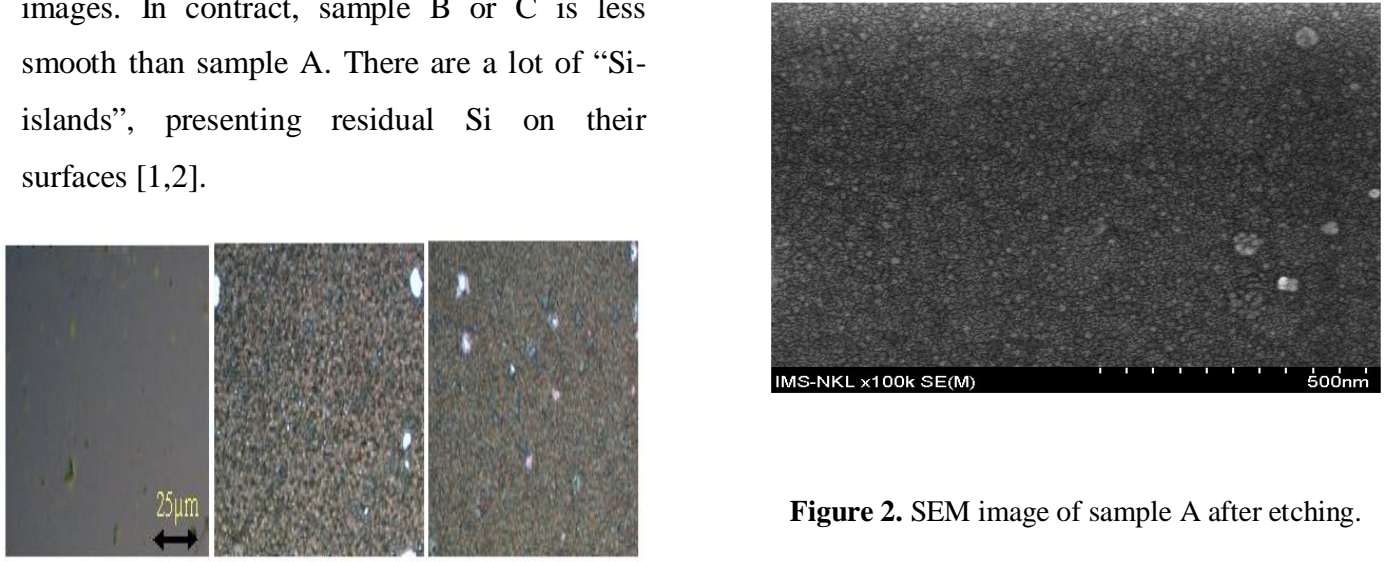

Sample A

Sample B

Sample C

Figure 1. Optical transmission microscopy images of three samples (A, B, C).
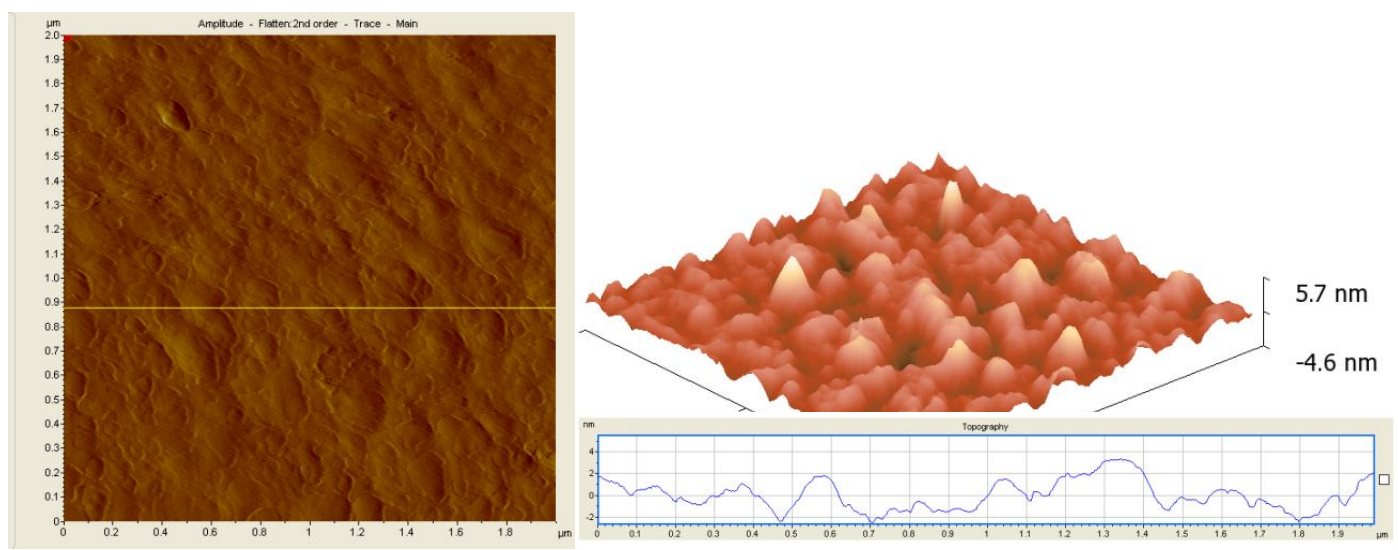

Figure 3. AFM image of the sample A

Fig. 2 shows SEM image of the sample A with uniform grain sizes of about 20-30 nanometers. This image is different from the ones of the samples containing "Si islands" on the surface reported by other authors $[3,4]$. This reveals that sample A represent a continuous poly-Si thin film without above residual Si.
In addition,the AFM image in Fig. 3 shows the surface morphology with average surface roughness of about $2.8 \mathrm{~nm}$ in scanned $2 \mu \mathrm{m}^{2}$ area. The surfaceis quite smoother than the one reported by G. J. Qi et al. [5] (R $\alpha \sim 5 \mathrm{~nm}$ for $160 \mathrm{~nm}$ thickness and $\mathrm{R} \alpha \sim 16 \mathrm{~nm}$ for $80 \mathrm{~nm}$ 
thickness). This result indicates that asmooth poly-Si thin film has been obtained.

\subsection{Crystallinity and electrical conductivity}

The crystallinity of the Si layer after AIC process are investigated by XRD measurement.

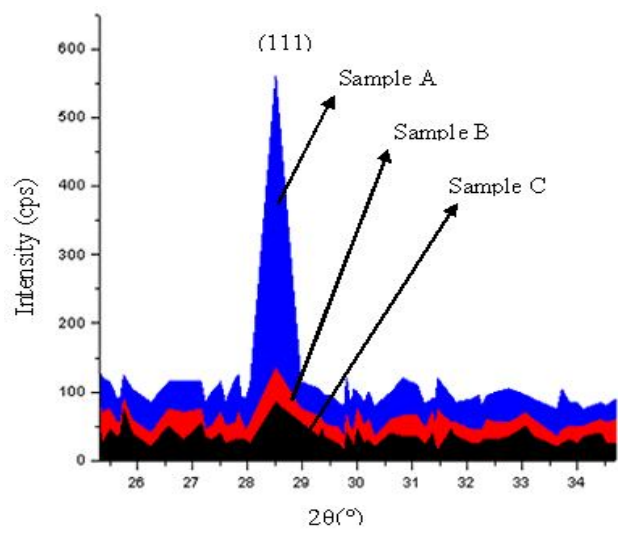

Figure 4. XRD profiles of three samples showed strong (111) orientation.

Fig 4 shows XRD profiles of $A, B, C$ samples. In that, sample A reveals a strong $\mathrm{Si}$ (111) peak at 2 theta angle of $28.5^{\circ}$. Samples B and C also showSi (111) peaks but the crystallization is less than sample A. It is possible to infer that samples with residual $\mathrm{Si}$ on their surface have a low quality of crystallographic properties. For this reason, their electron mobilities showed in Table 1 are very different.
Carrier concentrations of three samples havethe same values in the range of $10^{18} \mathrm{~cm}^{-3}$. These values do not change much for poly-Si thin film prepared by AIC [6]. The mobility of sample $\mathrm{A}$ is three times greater than one of sample B and two times greater than one of sample C. It is possible to conclude that electrical conductivity of sample A, which does not have residual islands on its surface, is better than ones of the others. The resistivities of samples $\mathrm{B}$ and $\mathrm{C}$ areabout one order ofmagnitude larger than one of sample A.

In order to estimate $\mathrm{Al}$ content within the poly-Si thin film, EDX analysis is used. The result in Fig. 5 reveals a small amount of aluminum embedded in the final crystallized sample A.The $1.98 \%$ percent of $\mathrm{Al}$ atoms is not very high if Aluminum is considered as an acceptor dopant in $\mathrm{Si}$ material.Because Aluminum is a shallow acceptor dopant, it leads the samples to p-type conduction.The result also shows that amount of oxygen are also incorporated in the film. This oxygen content is attributed to the formation of a thin native oxide on the surface caused by annealing sample at high temperature or by using mixture of acidsto remove $\mathrm{Al}$ on the surface of the sample.

Table 1. Results of Hall effect measurements of A, B, C samples

\begin{tabular}{|c|c|c|c|}
\hline Sample & Carrier concentration $\left(\mathbf{c m}^{-3}\right)$ & Mobility $\left(\mathbf{c m}^{2} / \mathbf{V s}\right)$ & Resistivity $(\mathbf{\Omega . c m})$ \\
\hline A & $1.7 \times 10^{18}$ & 48 & $7,8 \times 10^{-2}$ \\
\hline B & $2,4 \times 10^{18}$ & 16 & $1,6 \times 10^{-1}$ \\
\hline C & $1,5 \times 10^{18}$ & 23 & $1,8 \times 10^{-1}$ \\
\hline
\end{tabular}


TÄ̈ CHÍ PHAÙ TRIEÅ KH\&CN, TAZ̈ 16, SOÁK1- 2013

\begin{tabular}{|c|c|c|c|c|c|c|}
\hline \multicolumn{7}{|c|}{ Fitting Coefficient : 0.4325} \\
\hline Element & $(\mathrm{keV})$ & Mass\% & Counts & Error: & At om응 & $\mathrm{K}$ \\
\hline $\mathrm{O} \mathrm{K}$ & 0.525 & 12.21 & 1538.08 & 0.02 & 19.61 & 0.8522 \\
\hline Al $\mathrm{K}$ & 1.486 & 2.33 & 278.05 & 0.19 & 2.22 & 0.8986 \\
\hline$(\operatorname{Ref})$. & 1.739 & 85.46 & 9170.23 & 0.01 & 78.17 & 1.0000 \\
\hline Total & & 100.00 & & & 100.00 & \\
\hline
\end{tabular}

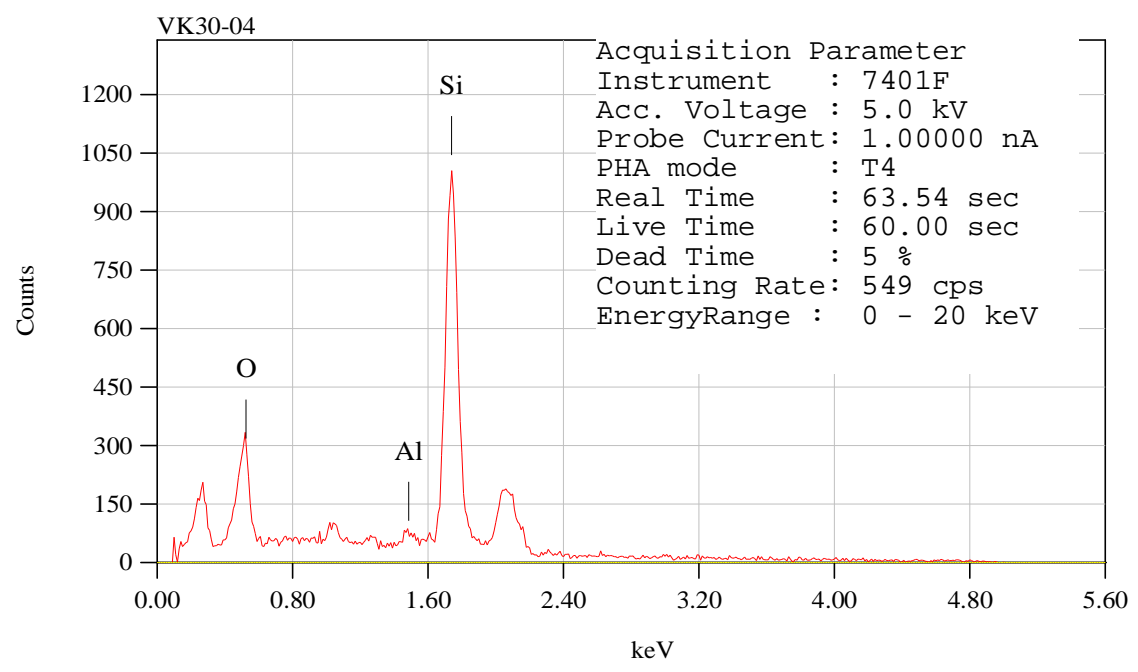

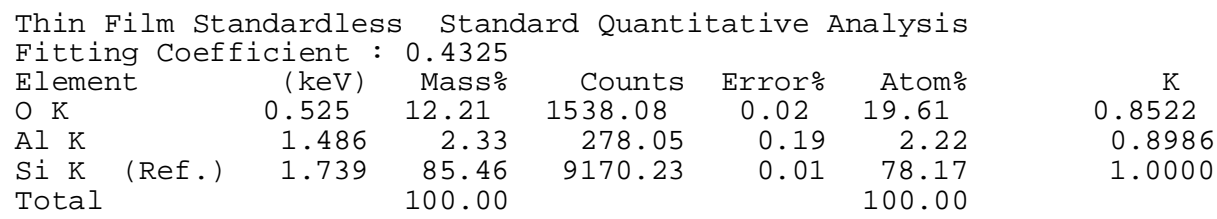

Figure 5. EDX spectrocopy of sampleA.

\section{CONCLUSIONS}

Bychoosing an appropriate thickness ratio of initial $\mathrm{Al}$ and $\mathrm{Si}$ layers, we obtain the best sample with little residual $\mathrm{Si}$ on the surface.
The crystalline structure, surface morphology, and electrical conductivity analyses show a strong influence of thickness ratio of initial bilayer on the formation of high-quality polycrystalline silicon thin film by AIC. 


\title{
SỰ HÌNH THÀNH MÀNG SILICON ĐA TINH THỄ BẰNG PHƯƠNG PHÁP NHÔM THÚC ĐẨY TINH THỂ HÓA
}

\author{
Phan Tú Linh, Phạm Duy Phong, Phan Bách Thắng, Trần Cao Vinh \\ Trường Đại học Khoa học Tự nhiên, ĐHQG-HCM.
}

TÓM TĂT: Màng silic đa tinh thể kết tinh tốt, dẫn điện loại p được chúng tôi chế tạo bằng phuơng pháp nhôm thúc đẩy tinh thể hóa. Trong phuơng pháp này, cấu trúc màng đa lớp gồm: đế thủy tinh / Al / silic vô định hình (a-Si) sẽ chuyển đổi thành cấu trúc: đế thủy tinh / silic đa tinh thể (poly-Si) / $\mathrm{Al}\left(+\right.$ silic du) chỉ bằng cách xử lý mẫu ở $500^{\circ} \mathrm{C}$ sau 5 giờ trong lò nung chân không. Kết thúc quá trình, màng silic đa tinh thể được hình thành trên đế thủy tinh sau khi lớp nhôm du được loại bỏ bằng cách xủ lý mẫu bằng phương pháp hóa học thông thường. Tuy nhiên, trên bề mặt màng silic đa tinh thể thu được thông thường vẫn còn rất nhiều các "ốc đảo silic" du sót lại sau quá trình loại bỏ nhôm. Trong nghiên cứu này, chúng tôi đưa ra cách thức đơn giản, có khả năng hạn chế các silic du còn lại trên bề mặt của màng silic đa tinh thể thu được bằng cách thay đổi tỷ lệ bề dày của lớp kim loại Al và silic ban đầu. Kết quả cho thấy với tỷ lệ bề dày của lớp Al/a-Si ban đầu là 110/230 nm, màng silic đa tinh thể thu được hầu nhu đã loại bỏ được hết các silic du trên bề mặt. Các phân tích nhu OTM, SEM, $A F M, X R D, E D S$ và đo tính chất điện bằng phuoong pháp Hall cũng đã chứng minh tính chất tốt của một màng silic đa tinh thể thu được ở tỷ lệ bề dày trên bằng phương pháp nhôm thúc đẩy tinh thể hóa.

Tù̀ khóa:màng silic đa tinh thể,phương pháp nhôm thúc đẩy tinh thể hóa.

\section{REFERENCES}

[1]. Per I. Widenborg, Armin G. Aberle, Surface morphology of poly-Si films made by aluminium-induced crystallisation on glass substrates, Journal of Crystal Growth 242, 270-282 (2002).

[2]. Zhengxia Tang, Honglie Shen, Haibin Huang, Linfeng Lu, Yugang Yin, Hong Cai, Jiancang Shen, Preparation of high quality polycrystalline silicon thin films by aluminum-induced crystallization, Thin Solid Films 517, 5611-5615(2009).

[3]. Ozgenc Ebil, Roger Aparicio, Robert Birkmire, Alumium-induced crystallization of amorphous silicon films deposited by hot wire chemical vapor deposition on glass substrate, Thin Solid Films 519, 178183(2010).

[4]. Cheng-Chang Peng, Chen-Kuei Chung, Jen-Fin-Lin, Formation of microcrystalline silicon films using rapid crystal aluminum induced crystallization under lowtemperature rapid thermal annealing, Thin Solid Films 518, 6966-6971(2010).

[5]. G. J. Qi, S. Zhang, T. T. Tang, J. F. Li, X. W. Sun, X. T. Zeng, Experimental study of Aluminum crystallization of amorphous 


\section{TAP̈ CHÍ PHAÙ TRIEÂ KH\&CN, TAR̈ 16, SOÁK1- 2013}

Silicon thin films, Surface \& Coatings Technology, Singapore (2005).

[6]. Stefan Gall, Polycrystalline Silicon Thin-

Films formed by Aluminum - Induced
Layer Exchange ALILE Process, Springer, 205. 